\title{
SUBSTRACT AND TEMPERATURE EFFECT ON XYLANASE PRODUCTION BY ASPERGILLUS FUMIGATUS USING LOW COST AGRICULTURAL WASTES
}

\author{
EFEITO DA TEMPERATURA E DO SUBSTRATO NA PRODUÇÃO DE XILANASE \\ POR ASPERGILLUS FUMIGATUS UTILIZANDO RESÍDUOS AGROINDUSTRIAIS \\ DE BAIXO CUSTO
}

\begin{abstract}
Arthur Filipe Sousa GOMES' ${ }^{1}$ Bruna Silveira Lamanes dos SANTOS ${ }^{2}$; Emanuele Giuliani FRANSCISCON ${ }^{3}$; Milla Alves BAFFI ${ }^{4}$

1. Bacharel em Engenharia Ambiental, Universidade Federal de Uberlândia - UFU, Uberlândia, MG, Brasil. arthur_filipe2005@hotmail.com; 2. Bacharel em Engenharia Ambiental - UFU, Uberlândia, MG, Brasil; 3. Bacharel em Engenharia Ambiental - UFU, Uberlândia, MG, Brasil; 4. Professora, Doutora, Instituto de Ciências Agrárias - ICIAG - UFU, Uberlândia, MG, Brasil.millabaffi@iciag.ufu.br
\end{abstract}

\begin{abstract}
This study reports the optimization of xylanase production under solid state fermentation (SSF) by a thermotolerant Aspergillus fumigatus strain (SCB4) isolated from sugarcane bagasse piles of Brazilian Cerrado. Different combinations of low-cost agricultural byproducts in SSF were evaluated: sugarcane bagasse and wheat bran (1:1), sugarcane bagasse and corn straw (1:1) and only sugarcane bagasse. The enzyme biosynthesis by SSF was carried out at different temperatures $\left(40,45,50\right.$ and $\left.55^{\circ} \mathrm{C}\right)$. The maximum levels of xylanase activity were obtained after $24 \mathrm{~h}$ at $45{ }^{\circ} \mathrm{C}$ using a culture medium containing sugarcane bagasse and wheat bran (1:1). Under optimal conditions, the fungal culture produced $574 \mathrm{U} \mathrm{g}^{-1}$ of xylanase (units/g of dry substrate). The crude enzyme showed optimal activity at $60{ }^{\circ} \mathrm{C}$ and $\mathrm{pH}$ 4.5. It exhibited thermostability up to $55^{\circ} \mathrm{C}$, wide range of $\mathrm{pH}$ stability and tolerance to ethanol, xylose and glucose. The physicochemical properties shown by this enzyme are appropriate for its application in hydrolysis of lignocellulosic residues for ethanol production and other bioproducts.
\end{abstract}

KEYWORDS: Sugarcane bagasse. Wheat brean. Corn straw. Xylanase, Aspergillus fumigatus.

\section{INTRODUCTION}

Xylan is the major polysaccharide of hemicelluloses and is the second most abundant polymer in plant cell wall. It consists of a homopolymeric backbone of $\beta-1.4$ linked $D$ xylopyranosyl units with short chain branches of Oacetyl, a-L-arabinofuranosyl, and a-D-glucuronyl residues (SÁNCHEZ, 2009). Xylanases ( $\beta-1,4-D-$ xylan-xylanohydrolase, EC 3.2.1.8) are the key enzymes responsible for the hydrolysis of xylan, providing the availability of cellulose for the action of cellulases and contributing for an increase in the efficiency of the process of biomass degradation (POLIZELI et al., 2005). These enzymes have high commercial applications. For instance, xylanases can be used in paper industry, in the improvement of the quality of animal feed, textile and food processing industries and also in the transformation of lignocellulosic materials in fermentable sugars for the production of second generation ethanol (NAIR et al., 2010; BAJAJ; ABBASS, 2011; SOUZA et al., 2012).

Filamentous fungi are known to be good producers of extracellular xylanases by solid-state fermentation (SSF) using lignocellulosic agricultural by-products as components of microbial growth media, with several economic advantages: low water output, cheap substrates, low risk of contamination and low operating costs (MORETTI et al., 2012; TERRASAN; CARMONA, 2015). Among these residues, sugarcane bagasse is one of the most important in Brazil and is composed by approximately $50 \%$ cellulose, $25 \%$ hemicellulose and 20\% lignin (PANDEY et al., 2000). Wheat bran is also a mostly available waste which comprises about $46 \%$ of polysaccharides (glucuronoarabinoxylans, cellulose, mixed linked (1-3)(1-4)- $\beta$-D-glucans and starch), proteins (15$22 \%$ ) and lignin (4-8\%) (SOUZA et al., 2012). These substrates have been tested as carbon sources for the production of cellulases and hemicellulases by fungal strains (LIU et al., 2011; DELABONA et al., 2013).

In industrial processes, thermotolerant xylanases are desirable since high temperatures are required to increase solubility of substrates, to reduce viscosity and to reduce the risk of contamination (MORETTI et al., 2012). As a result, the search for thermophilic microorganisms with potential for the synthesis of such enzymes has increased considerably in the last years, mainly 
filamentous fungi, which have been the most chiefly employed (JOSHI; KHARE, 2012; MORETTI et al., 2012).

The fungus Aspergillus fumigatus is a widespread species commonly found in agricultural residues with numerous biotechnological applications. Previous studies reported its ability to produce secondary metabolites with antimicrobial activity (ARAÇARI et al., 2002), and many enzymes such as proteases, cellulases and xylanases (OYELEKE et al. 2010; MORETTI et al., 2012; SOUZA et al., 2012). In this work, a thermotolerant A. fumigatus SCB4 strain isolated from sugarcane bagasse piles from Brazilian Cerrado was evaluated for the production of extracellular xylanase. Cultivation conditions of A. fumigatus SCB4 in SSF for enzyme biosynthesis were optimized. The physicochemical characteristics of the crude enzyme were also investigated.

\section{MATERIAL AND METHODS}

The filamentous fungus A. fumigatus SCB4 was obtained from the microbial collection of Laboratory of Environmental Microbiology, Uberlandia Federal University (LAMIC, UFU). This strain was previously isolated from internal portions of sugarcane piles (Araporã, Minas Gerais, Brazil, $18^{\circ} 26^{\prime} 13^{\prime \prime} \mathrm{S}$ and $49^{\circ} 11^{\prime} 13^{\prime \prime} \mathrm{W}$ ), identified by conventional morphological examination and by gene sequencing of ITS region from ribosomal DNA (dos SANTOS et al., 2015).

Aspergillus fumigatus SCB4 was cultivated under solid state fermentation (SSF) using three types of substrates: a mixture of sugar cane bagasse and wheat bran (SCB/WB, 1:1 w/w); sugar cane bagasse and corn straw (SCB/CS, 1:1 w/w) and only sugar cane bagasse (SCB) (Table 1). Sugar cane bagasse was obtained from a Brazilian ethanol industrial plant (Usina Alvorada, Araporã, MG). Before SSF, it was washed with distilled water, dried at $50{ }^{\circ} \mathrm{C}$ for $48 \mathrm{~h}$ and grinded to obtain particles of $2.0 \mathrm{~mm}$ (dos SANTOS et al., 2015). Wheat bran was brought from a local retailer and was submitted to the same process. Corn straw was obtained from a local farm. SSF was carried out using $2.5 \mathrm{~g}$ of each substrate (5 $\mathrm{g}$ in total) in erlenmeyer flasks of $250 \mathrm{~mL}$, containing $20 \mathrm{~mL}$ of sterile nutrient solution. The flasks were inoculated with a volume equivalent to $10^{7}$ spores $\mathrm{g}^{-1}$ of substrate suspended in a nutrient solution constituted by $\left(\mathrm{g} \mathrm{L}^{-1}\right)$ : $\left(\mathrm{NH}_{4}\right)_{2} \mathrm{SO}_{4}, 3.5 ; \mathrm{KH}_{2} \mathrm{PO}_{4}, 3.0$; $\mathrm{MgSO}_{4} 7 \mathrm{H}_{2} \mathrm{O}, 0.5 ; \mathrm{CaCl}_{2}, 0.5$ and Tween $80(1.0 \%$ $\mathrm{v} / \mathrm{v})$. SSF was performed during seven days at 45 ${ }^{\circ} \mathrm{C}$. To ascertain the time of peak of enzyme synthesis, protein extraction was carried out at intervals of $24 \mathrm{~h}$ with the addition of $100 \mathrm{~mL}$ of distilled water, followed by shaking at $100 \mathrm{rpm}$ for 1 $\mathrm{h}$. The samples were filtered and centrifuged at $15,000 \mathrm{rpm}$ for $20 \mathrm{~min}$ at $5^{\circ} \mathrm{C}$. The supernatant was used as crude enzymatic extract and stored at -20 ${ }^{\circ} \mathrm{C}$. In order to determine the optimal temperature of fungal growth and enzyme production, SSF fermentations were executed at the same conditions but at different temperatures: 40,50 and $55{ }^{\circ} \mathrm{C}$ (Table 1).

Table 1. Substrates and temperatures evaluated in SSF for optimization of xylanase production by A. fumigatus SCB4 strain.

\begin{tabular}{cc}
\hline Substrate & Temperature \\
\hline SCB/WB $(1: 1 \mathrm{w} / \mathrm{w})^{\mathrm{a}}$ & $40{ }^{\circ} \mathrm{C}$ \\
SCB/WB $(1: 1 \mathrm{w} / \mathrm{w})^{\mathrm{a}}$ & $45{ }^{\circ} \mathrm{C}$ \\
SCB/WB $(1: 1 \mathrm{w} / \mathrm{w})^{\mathrm{a}}$ & $50{ }^{\circ} \mathrm{C}$ \\
$\operatorname{SCB} / \mathrm{WB}(1: 1 \mathrm{w} / \mathrm{w})^{\mathrm{a}}$ & $55^{\circ} \mathrm{C}$ \\
$\operatorname{SCB} / \mathrm{CS}(1: 1 \mathrm{w} / \mathrm{w})^{\mathrm{b}}$ & $45^{\circ} \mathrm{C}$ \\
$\operatorname{SCB}^{\mathrm{c}}$ & $45^{\circ} \mathrm{C}$ \\
\hline
\end{tabular}

${ }^{\text {a }}$ Sugar cane bagasse + wheat bran $(1: 1) ;{ }^{b}$ Sugar cane bagasse + corn straw $(1: 1) ;{ }^{\mathrm{c}}$ Sugar cane bagasse

Xylanase activity was determined by 3,5dinitrosalicylic acid (DNS) method (MILLER, 1959). Reaction mixtures containing $10 \mu \mathrm{L}$ of crude enzymatic extract and $90 \mu \mathrm{L}$ of sodium acetate buffer $0.1 \mathrm{M}$, pH 5.0 with xylan $(1 \%)$ as substrate were incubated at $60{ }^{\circ} \mathrm{C}$ for $10 \mathrm{~min}$. The released reducing sugars were quantified at $540 \mathrm{~nm}$ using a xylose standard curve. One unit of enzyme activity (U) was defined as the amount of enzyme required to release one $\mu \mathrm{mol}$ of xylose per minute under the assay conditions. Control assays using heat inactivated enzymatic extract were carried out for each sample.

The optimum $\mathrm{pH}$ of xylanase was measured by DNS method incubating the reaction mixture at $60{ }^{\circ} \mathrm{C}$ for 10 min with buffer solutions at a $\mathrm{pH}$ range from 3.0 to 8.0 (dos SANTOS et al., 2015). The buffers used were: acetate buffer ( $\mathrm{pH} 3.0$ to 5.5); 
citrate / phosphate buffer ( $\mathrm{pH} 5.5$ at 7.0), and Tris / $\mathrm{HCl}(\mathrm{pH} 7.0$ at 8.5). Optimum temperature was obtained by the same method but incubating the reaction mixture at temperatures from 30 to $80{ }^{\circ} \mathrm{C}$ at the optimum $\mathrm{pH}$. To determine the $\mathrm{pH}$ stability, the extracts were diluted with acetate buffer at $\mathrm{pH}$ between 3.0 and 8.0 and incubated at room temperature for $24 \mathrm{~h}$. After this period, the residual enzymatic activity was quantified in optimum $\mathrm{pH}$ and temperature. To evaluate the thermostability, the enzymatic extracts were incubated for 1 hour at temperatures ranging from 30 to $80{ }^{\circ} \mathrm{C}$. After this period, the residual enzymatic activity was measured in optimum $\mathrm{pH}$ and temperature (dos SANTOS et al., 2015).

The effect of ethanol on xylanase activity was evaluated by the same method at the optimal $\mathrm{pH}$ and temperature, using increasing concentrations of ethanol in the reaction mixture $(0-40 \%)$. Likewise, the enzyme activity in the presence of sugars was evaluated in concentrations from 0 to 20
$\mathrm{mM}$ (glucose or xylose). All assays were performed in duplicates.

\section{RESULTS AND DISCUSSION}

The xylanase production was strongly affected by the initial moisture contents of the substrates and the results were different for each evaluated carbon source (Figure 1). Maximum xylanase activity (574 $\mathrm{U} \mathrm{g}^{-1}$ ) was achieved using a mixture of sugarcane bagasse and wheat bran (1:1 $\mathrm{w} / \mathrm{w})$ after $24 \mathrm{~h}$ of SSF at $45{ }^{\circ} \mathrm{C}$. This enzymatic biosynthesis in a short period of time is advantageous for industrial processes because it permits more repetitions of the process and higher productivity. The enzyme production also varied considerably with the temperature. At the temperatures of 40,50 and $55{ }^{\circ} \mathrm{C}$ the enzyme production was smaller, indicating that these temperatures inhibited the growth of the microorganism and consequently its enzymatic production.

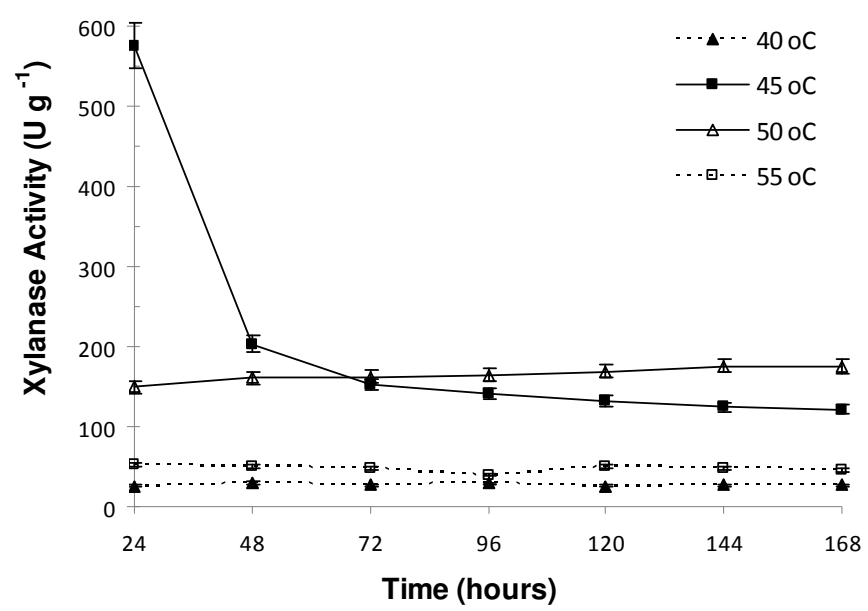

Figure 1. Xylanase production by A. fumigatus SCB4 using sugar cane bagasse and wheat bran (SCB/WB) at different temperatures.

The greatest biosynthesis of xylanase at 45 ${ }^{\circ} \mathrm{C}$ suggests that A. fumigatus SCB4 can be a thermotolerant fungal strain. Previous studies reported the effects of time and temperature during SSF on xylanase synthesis by other Aspergillus species and described higher production of xylanases at the same temperature (SALES et al., 2010, DELABONA et al., 2012). This peak of xylanase activity at $45{ }^{\circ} \mathrm{C}$ suggest that this mold can be employed in bioreactors at high temperatures, which could contribute to better conditions of operations, such as fluidity of the medium and reduction of the risk of contamination by mesophilic microorganisms (GOMES et al., 2007).
When wheat bran was substituted by corn straw a lower value of enzymatic activity was obtained (180 $\left.\mathrm{U} \mathrm{g}^{-1}\right)$ with a peak of activity after $168 \mathrm{~h}$ of SSF (Figure 2). This result indicates that the use of corn straw in SSF is not advantageous for xylanase production. In addition, SSF with sugarcane bagasse as single substrate obtained only $72 \mathrm{U} \mathrm{g}^{-1}$ of xylanase after $96 \mathrm{~h}$, confirming the higher efficiency of fermentation using sugarcane bagasse and wheat bran for enzyme assembly and indicating that the simultaneous reuse of these two residues is a positive combination for biomass degradation. 


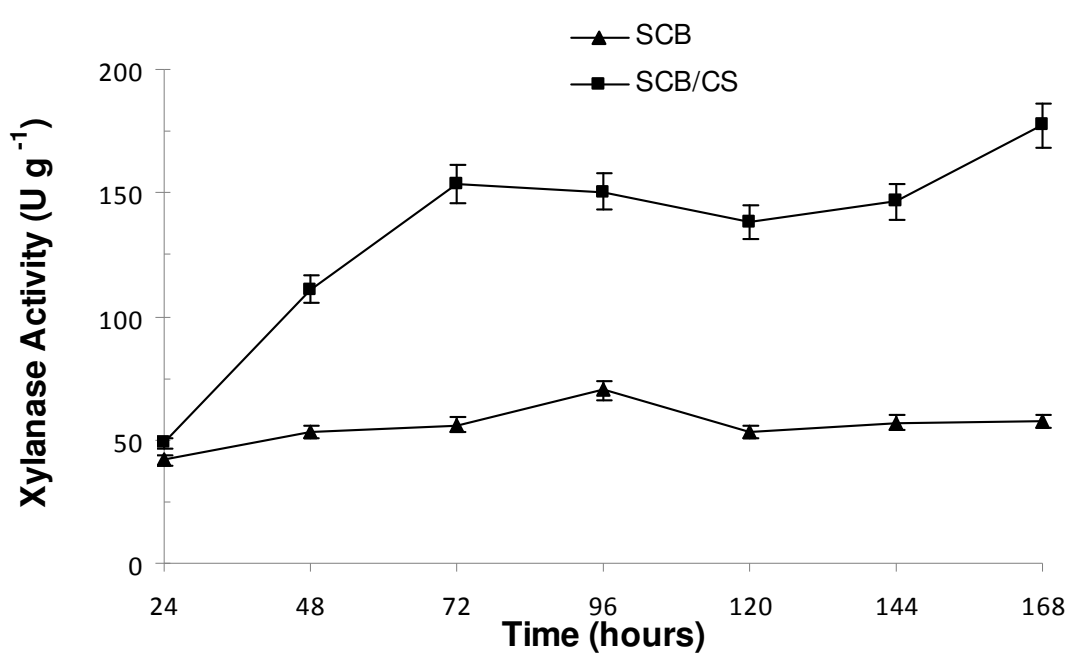

Figure 2. Xylanase production by A. fumigatus SCB4 using sugar cane bagasse and corn straw (SCB/CS) and only sugarcane bagasse (SCB) at $45^{\circ} \mathrm{C}$.

Maximum xylanase activity was obtained at $\mathrm{pH} 4.5$ showing a typical profile of an acidophilic enzyme (Figure 3A). Moreover, $80 \%$ of the optimum activity was obtained at $\mathrm{pH}$ range of 3.5 to 5.0. Other studies reported an acid optimum $\mathrm{pH}$ for xylanase from A. fumigatus strains (MORETTI et al., 2012; SOUZA et al., 2012). Optimum temperature was observed at $60{ }^{\circ} \mathrm{C}$, suggesting that this xylanase can be a thermophilic enzyme which can be useful for many biotechnological processes which operate at high temperatures (Figure 3B). This characteristic confers to this enzyme potential uses in the industry since its action represents a key step for efficient biomass degradation in saccharification processes where high temperatures are aimed (DELABONA et al., 2013). Enzymes with high optimal temperatures are also resistant to detergent agents, to proteolytic enzymes and are stable to a wide range of $\mathrm{pHs}$, increasing their application in different conditions and processes (GOMES et al., 2007).

The enzyme showed high stability in a wide $\mathrm{pH}$ range with a highlighted residual activity of more than $80 \%$ after an overnight exposition at $\mathrm{pH}$ 3.0 (Figure 3C). This stability in acid $\mathrm{pH}$ values shows the potential application of such enzyme in industrial bioprocesses such as the production of bioethanol (PEIXOTO-NOGUEIRA et al., 2009). The xylanase enzyme also showed high stability up to $55{ }^{\circ} \mathrm{C}$ (Figure 3D) and kept $86 \%$ of the maximum activity at $50{ }^{\circ} \mathrm{C}$, indicating a higher stability when compared to other studies (KALOGERIS et al., 2003; KANG et al., 2004).
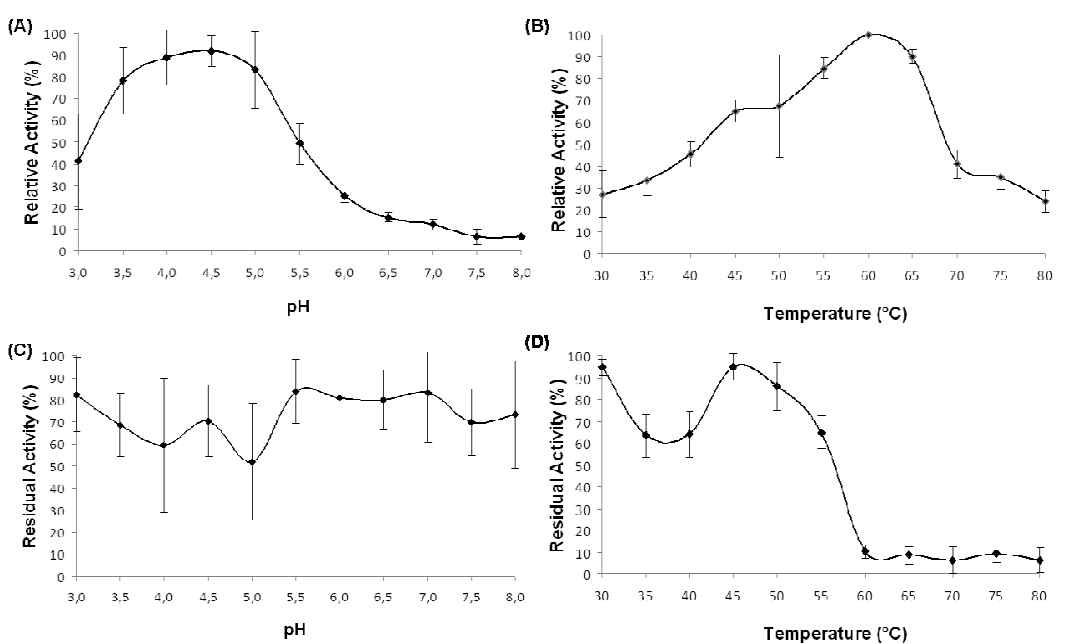

Figure 3. Effect of $\mathrm{pH}$ and temperature on the activity and stability of A. fumigatus SCB4 xylanase: (A) optimum $\mathrm{pH}$; (B) optimum temperature; (C) pH stability and (D) thermostability. 
The effect of sugars which are released after the hydrolysis of lignocellulosic biomass was evaluated on xylanase activity, as well as the inhibitory effect of the ethanol as the final product of the alcoholic fermentation. The enzyme was tolerant to ethanol, showing tolerance up to $40 \%$ of ethanol (Table 2). Previous studies in literature reported cellulases and hemicellulases which are inhibited by ethanol (van DYK et al., 2010; BAFFI et al., 2011). In the present study, the enzyme remained $75 \%$ of residual activity at $40 \%$ of ethanol showing high tolerance to this compound. At the levels of ethanol assessed, high enzyme activity was still present being this xylanase also suitable for application in alcoholic fermentations. As regards the effect of sugars on enzymatic activity, the enzyme showed reasonable tolerance to glucose and xylose with nearly $70 \%$ of residual activity maintained up to $20 \mathrm{mM}$ of each sugar (Table 2). Few studies in literature reported resistance to xylose by microbial xylanases (van DYK et al, 2010).

Table 2. Effects of ethanol and sugars on the activity of xylanase from A. fumigatus SCB4.

\begin{tabular}{cc}
\hline Substance & Xylanase tolerance \\
\hline Ethanol & Up to $40 \%$ \\
Xylose & Up to 20mM \\
Glucose & Up to 20mM \\
\hline
\end{tabular}

\section{CONCLUSIONS}

The optimization of SSF showed high levels of xylanase production by A. fumigatus SCB4 strain using sugarcane bagasse and wheat bran as substrates after $24 \mathrm{~h}$ at $45^{\circ} \mathrm{C}$.

The enzyme was characterized as acidophilic, thermophilic and stable over a broad $\mathrm{pH}$ range. It also showed thermostability, high tolerance to ethanol and moderate sensitivity to reducing sugars. These properties are favorable for application in advanced industrial processes and support data for further research involving the reuse of agro-industrial residues for the production of bioproducts from renewable sources.

\section{ACKNOWLEDGMENTS}

This research was supported by the National Counsel of Technological and Scientific Development $(\mathrm{CNPq})$ and Federal University of Uberlândia (Propp-UFU).

RESUMO: Este estudo descreve a otimização da produção de xilanase por fermentação em estado sólido (FES) por uma linhagem termotolerante de Aspergillus fumigatus isolada de pilhas de bagaço de cana-de-açúcar do Cerrado Brasileiro (linhagem SCB4). Combinações de diferentes subprodutos agrícolas de baixo custo foram avaliadas como substratos na FES: bagaço de cana-de-açúcar e farelo de trigo (1:1), bagaço de cana-de-açúcar e palha de milho (1:1) e somente bagaço de cana-de-açúcar. A produção da enzima por FES foi realizada em diferentes temperaturas (40, 45, 50 e $\left.55{ }^{\circ} \mathrm{C}\right)$. Níveis máximos de xilanase $\left(574 \mathrm{U} \mathrm{g}^{-1}\right.$ de substrato seco) foram obtidos após $24 \mathrm{~h}$ a $45{ }^{\circ} \mathrm{C}$, utilizando bagaço de cana-de-açúcar e farelo de trigo $(1: 1)$ no meio de cultura. $\mathrm{O}$ extrato enzimático bruto apresentou atividades ótimas a $60{ }^{\circ} \mathrm{C}$ e pH 4,5. A enzima exibiu estabilidade térmica até $55^{\circ} \mathrm{C}$, ampla faixa de $\mathrm{pH}$ de estabilidade e tolerância ao etanol, xilose e glucose. Tais propriedades físico-químicas indicam que o extrato enzimático obtido é apropriado para aplicação na hidrólise de resíduos lignocelulósicos para a produção de etanol e outros bioprodutos. fumigatus

PALAVRAS-CHAVE: Bagaço de cana-de-açúcar. Farelo de trigo. Palha de milho. Xilanase. Aspergillus

\section{REFERENCES}

ARAÇARI, N.; FURTADO, J. C.; SAID, S.; ITO, I. Y.; BASTOS, J. K. The antimicrobial activity of Aspergillus fumigatus is enhanced by a pool of bacteria. Microb. Res., Copenhagen, v. 157, n. 3, p. 207-211, 2002.

BAFFI, M. A.; TOBAL, T.; LAGO, J. H. G.; LEITE, R. S. R.; BOSCOLO, M.; GOMES, E. DA-SILVA, R. A Novel $\beta$-Glucosidase from Sporidiobolus pararoseus: Characterization and Application in Winemaking. J.

Food Sci., North Carolina, v. 76, n. 7, p. 997-1002, 2011. 
BAFFI, M. A.; ROMO-SÃNCHEZ, S.; UBEDA-IRANZO, J.; BRIONES-PEREZ, A. I. Fungi isolated from olive ecosystems and screening of their potential biotechnological use. New Biotechnol., Cambridge, v. 29, n. 3, p. 451-456, 2012.

BAJAJ, B. K.; ABBASS, M. Studies on an alkali-thermostable xylanase from Aspergillus fumigatus MA28. 3 Biotechnol., Brisbane, v. 1, n. 3, p. 161-171, 2011.

DELABONA, P. S.; PIROTA, R. D. P. B.; CODIMA, C. A.; TREMACOLDI, C. R.; RODRIGUES, A.; FARINAS, C. S. Using Amazon forest fungi and agricultural residues as a strategy to produce cellulolytic enzymes. Biomass Bioen., Aberdeen, v. 37, p. 243-250, 2012.

DELABONA, P. S.; PIROTA, R. D. P. B.; CODIMA, C. A.; TREMACOLDI, C. R.; RODRIGUES, A.; FARINAS, C. S. Effect of initial moisture content on two Amazon rainforest Aspergillus strains cultivated on agro-industrial residues: Biomass-degrading enzymes production and characterization. Ind. Crops Prod., St Martin d'Heres, v. 42, n. 1, p. 236-242, 2013. http://dx.doi.org/10.1016/j.indcrop.2012.05.035

DOS SANTOS, B. S. L.; GOMES, A. F. S.; FRANCISCON, E. G.; OLIVEIRA, J. M.; BAFFI, M. A. Thermotolerant and mesophylic fungi from sugarcane bagasse and their prospection for biomass-degrading enzyme production. Braz. J. Microb., São Paulo, v. 46, n. 3, p. 903-910, 2015.

GOMES, E.; AGUIAR, A. P.; BOSCOLO, M.; CARVALHO, C. C.; BONFÁ, M. R. B., SILVA, R., BOSCOLO, M. Ligninases production by basidiomicetes strains on lignocellulosic agricultural residues and decolorization of synthetic dyes. J. Biotechnol., Bielefeld, v. 131, n. 2, p. S228, 2007.

JOSHI, C.; KHARE, S. K. Induction of xylanase in thermophilic fungi Scytalidium thermophilum and Sporotrichum thermophile. Braz. Arch. Biol. Technol., Curitiba, v. 55, n. 1, p. 21-27, 2012.

KALOGERIS, E.; CHRISTAKOPOULOS, P.; KATAPODIS, P.; ALEXIOU, A.; VLACHOU, S.; KEKOS, D.; MACRIS, B. J. Production and characterization of cellulolytic enzymes from the thermophilic fungus Thermoascus aurantiacus under solid state cultivation of agricultural wastes. Process Biochem., Vandoeuvre Cedex, v. 38, n. 7, p. 1099-1104, 2003.

KANG, S. W.; PARK, Y. S.; LEE, J. S.; HONG, S. I.; KIM, S. W. Production of cellulases and hemicellulases by Aspergillus niger KK2 from lignocellulosic biomass. Biores. Technol., Trivandrum, v. 91, n. 2, p. 153-156, 2004.

LIU, D.; ZHANG, R.; YANG, X.; WU, H.; XU, D.; TANG, Z.; SHEN, Q. Thermostable cellulase production of Aspergillus fumigatus Z5 under solid-state fermentation and its application in degradation of agricultural wastes. Int. Biodet. Biodegr., Hong Kong, v. 65, n. 5, p. 717-725, 2011.

MORETTI, M. M. S.; MARTINS, D. A. B.; DA SILVA, R.; RODRIGUES, A.; SETTE, L. D.; GOMES, E. Selection of thermophilic and thermotolerant fungi for the production of cellulases and xylanases under solidstate fermentation. Braz. J. Microb., São Paulo, v. 43, n. 3, p. 1062-1071, 2012.

MILLER, G. L. Use of dinitrosalicylic reagent for determination of reducing sugar. Anal. Chem., UrbanaChampaign, v. 31, n. 3, p. 426-428, 1959.

NAIR, S. G.; SINDHU, R.; SHASHIDHAR, S. Enzymatic bleaching of kraft pulp by xylanase from Aspergillus sydowii SBS 45. Indian J. Microb., Delhi , v. 50, p. 332-338, 2010.

OYELEKE, S. B.; EGWIM, E. C.; AUTA, S. H. Screening of Aspergillus flavus and Aspergillus fumigatus strains for extracellular protease enzyme production. J. Microb. Antimicrob., Marseille, v. 2, n. 7, p. 83-87, 2010. 
PANDEY, A.; SOCCOL, C. R.; MITCHELL, D. New developments in solid state fermentation: I-bioprocesses and products. Process Biochem., Vandoeuvre Cedex, v. 35, n. 10, p. 1153-1169, 2000.

PEIXOTO-NOGUEIRA, S. C.; MICHELIN, M.; BETINI, J. H. A.; JORGE, J. A.; TERENZI, H. F.;

POLIZELI, M. L. T. M. Production of xylanase by Aspergilli using alternative carbon sources: application of the crude extract on cellulose pulp Biobleaching. J. Ind. Microb. Biotechnol., Houston, v. 36, n. 1, p. 149$155,2009$.

POLIZELI, M. L. T. M.; RIZZATTI, A. C. S.; MONTI, R.; TERENZI, H. F.; JORGE, J. A.; AMORIM, D. S. Xylanases from fungi: properties and industrial applications. Appl. Biochem. Microbiol., Moscow, v. 67, n. 5, p. 577-591, 2005.

SALES, M. R.; de MOURA, R. B.; PORTO, T. S.; de MACEDO, G. R.; PORTO, A. L. F. Variáveis que influenciam a produção de celulases e xilanase por espécies de Aspergillus. Pesq. Agropec. Bras., Brasília, v. 45, n. 11, p. 1290-1296, 2010.

SÁNCHEZ, C. Lignocellulosic residues: Biodegradation and bioconversion by fungi. Biotechnol. Adv., Rehovot, v. 27, n. 2, p. 185-194, 2009.

SOUZA, D. T.; BISPO, A. S. R.; BON, E. P. S.; COELHO, R. R. R.; NASCIMENTO, R. P. Production of thermophilic endo-b-1,4-xylanases by Aspergillus fumigatus FBSPE-05 using agro-industrial byproducts. Appl. Microbiol. Biotechnol., Münster, v. 166, p. 1575-1585, 2012.

TERRASAN, C. R. F.; CARMONA, E. C. Solid-state fermentation of brewer's spent grain for Xylanolytic enzymes production by Penicillium janczewskii and analyses of the fermented substrate. Biosci. J., Uberlândia, v. 31, n. 6, p. 1826-1836, 2015.

van DYK, J. S.; SAKKA, M., SAKKA, K., PLETSCHKE, B. I. Characterization of the multi-enzyme complex xylanase activity from Bacillus licheniformis SVD1. Enzyme Microb. Technol., Atlanta, v. 47, n. 4, p. 174$177,2010$. 